ENTREPRENEURSHIP AND SUSTAINABILITY ISSUES

ISSN 2345-0282 (online) http://jssidoi.org/jesi/

2020 Volume 7 Number 3 (March)

http://doi.org/10.9770/jesi.2020.7.3(44)

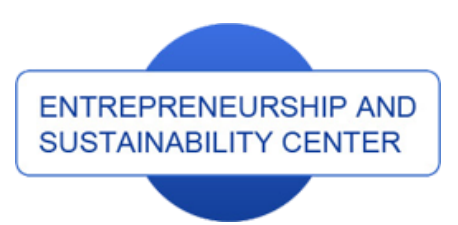

Publisher

$\underline{\text { http://jssidoi.org/esc/home }}$

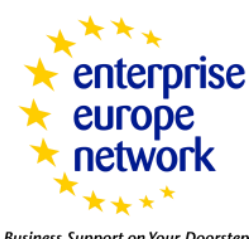

Business Support on Your Doorstep

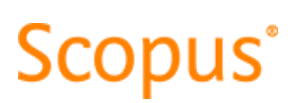

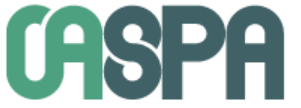

\title{
DIGITAL SUPPORT TO EXTERNAL SUSTAINABILITY COMMUNICATION IN SELF-ADHESIVE
} LABELLING INDUSTRY*

\author{
Mariana Tesařová $^{1}$, Aleš Krmela ${ }^{2}$, Iveta Šimberová $^{3}$ \\ 1,2,3 Brno University of Technology, Kolejni 2906/4 61200 Brno, Czech Republic \\ E-mails: ${ }^{1}$ mariana.tesarova@vut.cz ; ${ }^{2}$ ales.krmela@vut.cz $;{ }^{3}$ simberova@fbm.vutbr.cz
}

Received 18 August 2019; accepted 10 December 2019; published 30 March 2020

\begin{abstract}
The article presents results of empirical research conducted on companies in Europe in the field of paper production and processing, specifically in the field of production of self-adhesive laminate that is used for self-adhesive labels. The article is focused both on companies that either produce (category 1), or process (category 2) paper. The main goal was to understand, describe and compare content and extent of the digitally supported external communication, with a focus on the communication of sustainable development goals, supporting a transition to business models for sustainability. The article's objective is to present some of the findings from this research to provide an overview of a degree of online external communication supported by digitalization and characteristics of the industry within the scope of sustainability and transition to business models for sustainability. External communication is focused on companies' websites, GRI reports, annual corporate sustainability reports and participation in the Communication on Progress composed by the United Nations. The original research design combines relevant theory and content analysis to answer the later mentioned research questions. To conclude, digitally supported communication in the paper industry is intense in category 1, while category 2 seems to be less active in terms of both the intensity and the content. The article presents the theoretical background of the research, research design and methods, results, and conclusions presenting insights concerning the industry as well as the respective theory, introduced together with limitations and areas for future research.
\end{abstract}

Keywords: sustainability; communication; online communication; external communication; digitalization; business model; sustainable development goals

\footnotetext{
* This paper was supported by the research project: The challenges of digital transformation in the context of globalization, which is founded by Specific Research of FBM BUT, grant number FP-J-19-5909.
}
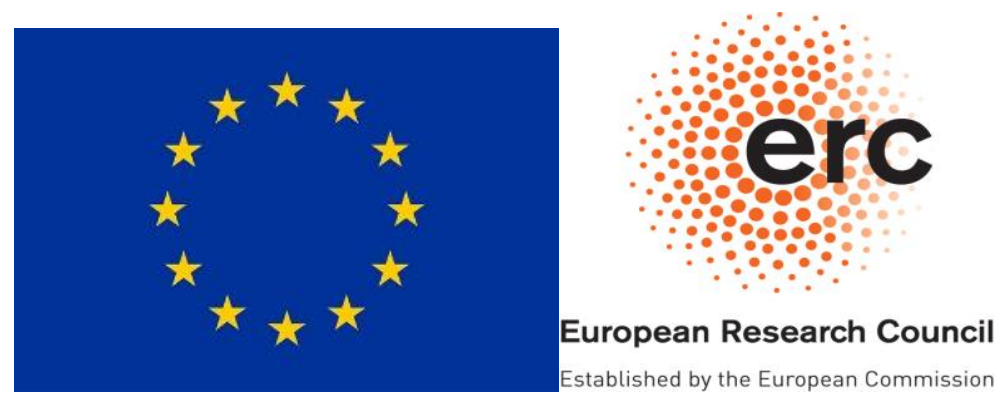


\section{ENTREPRENEURSHIP AND SUSTAINABILITY ISSUES}

ISSN 2345-0282 (online) http://jssidoi.org/jesi/

2020 Volume 7 Number 3 (March)

http://doi.org/10.9770/jesi.2020.7.3(44)

Reference to this paper should be made as follows: Tesařová, M., Krmela, A., Šimberová, I. 2020. Digital support to external sustainability communication in self-adhesive labelling industry. Entrepreneurship and Sustainability Issues, 7(3), 2109-2125. https://doi.org/10.9770/jesi.2020.7.3(44)

JEL Classifications: M14, M37, Q23

\section{Introduction}

Sustainability has become a buzzword in the 21st century (Ki \& Shin, 2015). In the meantime, a strong trend and efforts of businesses towards an extension of the business models and creation of business models for sustainable development (Boons \& Laasch, 2019) or business models focusing on sustainability targets (Raith \& Seibold, 2018) can be observed across continents, countries, industries. Sustainability seems to have become a new paradigm when it comes to doing legal business. Moreover, sustainability can be also determined by smart, skillful, management is a vital precondition of successful development of financially healthy businesses (Tvaronavičienè, 2018). A lot of new companies, being focused on contribution to the solution of societal or environmental issues, thus creating value for the society, have been founded. At the same time, incumbent companies, particularly in a field of business-to-business (B2B), spent effort in order to implement specific actions that contribute to the reduction or even elimination of non-sustainability resulting from their core activities. The source of pressure to do so can be manifold, coming either from the external environment and companies' external stakeholders, like governments, municipalities, authorities or from internal stakeholders, like shareholders, management or employees.

Sustainability has been defined as triple-bottom-line (Elkington, 1998), a three dimensional concept, incorporating social, environmental and economic performance (Elkington, 1998; Reilly \& Hynan, 2014), ideally all three dimensions being well balanced, thus forming a holistic concept and requiring a holistic and systemic approach, in business life ideally reflected in a corresponding business model for sustainability. True sustainability of such business models lies in the intersection, only such business is considered truly sustainable, which incorporates all three aspects (Schaltegger et al., 2016; Evans et al., 2017). Furthermore, sustainability represents the normative ethical principle enabling further development of society (Tvaronavičiené, 2012).

Guided by the United Nations, 193 member states agreed on a global scale on the agenda of promotion of a more sustainable future, whereas sustainable development goals (SDGs) address the global economic, social and environmental challenges that the whole society is facing, to leave no-one behind by 2030 . Therefore, SDGs are suitable for research of sustainability in any industry as businesses play a significant role in achieving these goals (The United Nations, 2019). Not only governments are the responsible agent in the process of building sustainable societies. Nowadays, it is generally understood that corporate actors and the private sector are crucial in the process of the creation of green growth outcomes as well as sustainable development. This new paradigm is now internationally recognized and anchored in international policy through SDGs (GRI, 2019). Not only the company needs to perform sustainable activities, but it is also vital to choose a proper way how to communicate its efforts towards the outside environment.

Due to the rapid pace of technological improvements, the need for accelerated adaptation is arising. The most innovative companies were able to recognize early how digitalization and new digital tools affect their business models. And furtherly, what value they can extract from the information generated by their activity (OECD, 2017; Castelo-Branco et al., 2019; Prodani et al., 2019; Petrenko et al., 2019). That is also the reason why more and more companies nowadays communicate through online channels as they understand the importance of digitalization. External communication, in particular, has proven to be vital for organizations in terms of stakeholders' relationship-building, more specifically in organizations' efforts to involve the larger community of stakeholders, and consequently build social legitimacy on both internal and external level (Ravazzani, 2016). 


\section{ENTREPRENEURSHIP AND SUSTAINABILITY ISSUES}

ISSN 2345-0282 (online) http://jssidoi.org/jesi/

2020 Volume 7 Number 3 (March)

http://doi.org/10.9770/jesi.2020.7.3(44)

Although this topic is really important, it has not received sufficient attention, especially in connection with the paper industry. Recent research on external communication has focused mainly on contemporary online contexts, more specifically on corporate websites (e.g. Pasztor, 2016; Point \& Singh, 2003; Maier \& Ravazzani, 2018), however, this article goes beyond corporate websites and also investigates communication through other digitallyenabled tools being freely accessible online for external audience. External communication about the sustainability activities of firms may vary significantly across different companies reflecting different communication channels, content, and frequency. All these aspects may reflect the company's priorities within resource allocation, its culture and also leadership in the sustainability domain (Reilly \& Naznin, 2018). In this article, we have chosen companies in the paper industry that are active in the field of paper production and processing, specifically in the field of production of self-adhesive laminate that is used for the production of selfadhesive labels. Within the scope of these companies, we focus on their digitally supported online external communication about sustainability on their websites, in annual sustainability reports, and their participation in Communication on Progress by UN and external rankings - the Global Reporting Initiative.

\section{Sustainability in a self-adhesive labelling industry}

Although we understand sustainability as a triple-bottom-line concept (Elkington, 1998), it might be, particularly by some practitioners or the wide public, narrowed down into its environmental dimension only. Environmental sustainability is of a vital focus of manufacturing companies (Chierici \& Copani, 2016), but not the only one. In the paper industry, the main raw material for paper production is wooden fibres, either virgin or recycled. According to the Monitoring Report 2017 of the European Paper Recycling Council, the recycling rate of all used paper in Europe has reached 72,3\% in 2017, or 59,6 million tons, out of a total of 82,4 million tons of all paper consumed in the same period (European Paper Recycling Council, 2017). According to the same study, Europe has outperformed compared to the total world with the recycling rate being $58,4 \%$. (ibid)

Our study focuses on a selected segment of the European paper industry, being the European market for a paper-based siliconized release liner. According to the authors' best knowledge, as well as based on fragmented self-adhesive labeling industry statistics obtained from industry insiders, expert companies or industry associations, the paper-based siliconized release liner market amounted in total approx. 12 bill $\mathrm{m} 2$ per year in 2017, and specifically a segment of paper-based self-adhesive laminate for labeling is estimated to be approx. 6,4 bill. M2 per year. Using a weight conversion factor of $80 \mathrm{~g} / \mathrm{m} 2$, the total paper-based release liner volume corresponds to approx. 960.000 of tons. The volume of self-adhesive laminate for labeling segment itself, using a conversion factor $140 \mathrm{~g} / \mathrm{m} 2$ (since two layers of paper - release liner and face stock - as well as adhesive are involved), corresponds to approx. 896.000 tons. Some $40 \%$ of the volume in a self-adhesive laminate for labeling, i.e. approx. 358.000 tons of the siliconized paper substrate - release liner - ends up after application of label to the product as a by-product resp. waste (being so-called spent liner). Following the principles of a circular economy-related waste pyramid, simplified into $4 \mathrm{R}$ framework of main focus areas, reducing, reuse, recycle, recover (Potting et al., 2016; Kirchherr et al., 2017), the industry takes efforts toward adhering to the waste reduction principles. For the time being, yet with partial success, what might be perceived as problematic when it comes to environmental sustainability. Precise and reliable data on what percentage of the spent liner falls into each of the $4 \mathrm{R}$ categories are not available. The reduction is reflected in regular efforts towards making the release liner lighter in weight. Reuse is technically currently not practicable in the field of the release liner. On the contrary, recycling and recovery are frequently applied ways of reprocessing the spent liner.

In this article, we focus specifically on the market of the self-adhesive labels, since the seemingly uneasily to recycle spent liner gains more and more attention of various stakeholders, thus being potentially considered as problematic when it comes to sustainability, esp. its environmental aspect. Although its share on the total European paper waste generated is comparably small, it is relevant to focus on it for numerous reasons. One is the fact that the self-adhesive labeling industry grows, thus generating more of the spent liner. AWA and FINAT 


\section{ENTREPRENEURSHIP AND SUSTAINABILITY ISSUES}

ISSN 2345-0282 (online) http://jssidoi.org/jesi/

2020 Volume 7 Number 3 (March)

http://doi.org/10.9770/jesi.2020.7.3(44)

estimate a CAGR of $4-5 \%$ over the last couple of years and assume a similar growth also for the years to come. Second, since involved companies have invested and continue to invest large amounts of money into producing and converting technologies and expect corresponding returns on investments over a longer period. Third, selfadhesive technology has proven itself to be a versatile, easy to use and thus popular one. It has gained momentum over competing technologies, esp. so-called wet glue labels, so typical in the beverage industry (esp. labeling of the returnable beer bottles). Last but not least, the industry employs Europe-wide substantial amount of people. Therefore, the sustainability of the entire industry stands in the focus of the attention of various stakeholders.

The paper producing and processing industry is relatively diversified and fragmented. Although the paper production process in its frame design, being the processing of the wooden fibres, remains the same for over centuries, the single paper grades, their specifics, as well as the end uses are numerous. Paper has been invented in ancient China even centuries b. C. as a novel medium for recording and keeping written information. That time perhaps as a cheaper and more practical solution than other available has over the time developed to a highly complex and technological process and product, involving huge investment, high-speed producing equipment, special skills handed over from one generation to the next, secret recipes known to only a small circle of insiders. The paper industry has got in the recent decades under significant pressure of the society, partly deservedly, partly as a victim of targeted false propaganda and numerous misunderstandings or misinterpretations. No doubt, several raw materials - called pulp - producers have harvested forests and trees unsustainably, following only economic profits, not considering the environmental aspects at all. A Brazilian rain-forest being a typical example of it. However, particularly in the last couple of decades, a clear trend towards sustainable forestry and sustainable sourcing is an industry dominant one. A number of measures have been taken, standards and certifications have been introduced. Particularly FSC ${ }^{\circledR}$ (forest stewardship council) and PEFC $^{\mathrm{TM}}$ (the program for the endorsement of forest certification) are in the meantime widely accepted and requested standards, when it comes to sustainable production and sourcing of fibre-based products. Numerous other activities, both in terms of environmental as well as social engagement are conducted and promoted or conducted but not promoted, or only promoted, but not fully conducted. A window dressing might still exist, especially under the impression, that being environmentally or socially sustainable leads to a positive image, which directly or indirectly leads to increasing company value, attract new customers, employees, shareholders. Thus, it is believed that a good performance in environmental and social fields goes hand in hand with good economic results.

An important aspect is the communication of the sustainability-related efforts and results, thus reaching out to the relevant stakeholders, making them aware of the sustainability-related performance. Most typical communication means is annual sustainability reports, published both in paper and online versions. Especially in the digital age, digitally-enabled tools are present, thus businesses can make much wider, faster, more efficient use of the online channels. Numerous companies, therefore, devote a significant part of their external communication to the aspects of sustainability. The way paper making and paper converting companies communicate about their sustainability efforts, with focus on online channels, have therefore been a core focus of our research.

\section{The Sustainable Development Goals (SDGs)}

Not only governments but also corporate actors and the private sector are vital in creating sustainable societies, green growth outcomes, and sustainable development. This new paradigm is internationally recognized and communicated through SDGs (GRI, 2019). SDGs consist of 17 goals that are composed of 169 targets in total (UPM, 2019), SDGs aim to achieve a better and sustainable future for all, while addressing global challenges, such as poverty, inequality, climate change, environmental degradation, peace, and justice. All 17 goals are interconnected. These goals represent a call for action by all countries and encourage them to promote prosperity while protecting the planet. Ending poverty must go hand-in-hand with strategies that build economic growth while at the same time addressing a range of social needs, such as education, health, social protection, and job opportunities, together with the focus on climate change and environmental protection (The United Nations Global Compact, 2019). 
ENTREPRENEURSHIP AND SUSTAINABILITY ISSUES

ISSN 2345-0282 (online) http://jssidoi.org/jesi/

2020 Volume 7 Number 3 (March)

http://doi.org/10.9770/jesi.2020.7.3(44)

17 SDGs:

1. No Poverty

2. Zero Hunger

3. Good Health and Well-Being

4. Quality Education

5. Gender Equality

6. Clean Water and Sanitation

7. Affordable and Clean Energy

8. Decent Work and Economic Growth

9. Industry, Innovation, and Infrastructure

10. Reduced Inequalities

11. Sustainable Cities and Communities

12. Responsible Consumption and Production

13. Climate Action

14. Life Below Water

15. Life on Land

16. Peace, Justice and Strong Institutions

17. Partnerships for The Goals (The United Nations, 2019)

\section{Global Reporting Initiative (GRI)}

90-95\% of the world's largest companies produce sustainability reports (Ernst and Young, 2014; King et al., 2015; Landrum \& Ohsowski, 2018). However, not all companies perceive reporting as a tool bringing them specific value and, therefore, not all companies choose to produce and submit sustainability reports (Stubbs et al., 2013). According to several researches, the GRI is perceived as the most commonly used format in terms of sustainability reporting (Calace, 2016; Ernst and Young, 2016, Landrum \& Ohsowski, 2018). In the GRI, participants are required to report on economic indicators, environmental compliance, labor practices, human rights, society, and product responsibility, thus the GRI framework provides standardization through these requirements. At the same time, the GRI framework allows each company the flexibility in reporting within these categories and subcategories (Landrum \& Ohsowski, 2018). Companies have a chance to report on the most crucial issues for the company and its stakeholders. Reports are maintained in a database that is publicly accessible and, according to the official website, the database contains over 23,000 GRI Reports recorded in the database whereas number continues to grow (GRI, 2019). GRI works in alignment with the UN Sustainable Development Goals (SDGs) and aims to foster inclusive development and sustainable, green, economic growth through the empowerment of decision-makers through their sustainability standards and multi-stakeholder network (GRI, 2019).

\section{The Communication on Progress (CoP)}

For companies committed to sustainability, it is vital to report to their stakeholders in a transparent and public manner. Annual Communication on Progress (CoP) represents a key component of the company's commitment to the UN Global Compact and UN SDGs. (The United Nations Global Compact, 2019). Submitting an annual CoP provides valuable information to the company's stakeholders and represents a meaningful way of how to communicate a company's sustainability efforts and actions. CoPs also works in the alignment with UN SDGs, thus enabling companies to communicate their activities towards specific SDGs as well. CoP collaborates with other frameworks, such as the GRI, to ensure alignment of standards and that meeting the requirements of one framework supports compliance with the others (The United Nations Global Compact, 2019).

Drawing from the theoretical background, the following research questions were formulated:

[1] To what extent companies externally communicate information about their activities towards sustainability?

[2] Which SDGs are the most common within the communication strategy of the sample of companies? 


\section{ENTREPRENEURSHIP AND SUSTAINABILITY ISSUES}

ISSN 2345-0282 (online) http://jssidoi.org/jesi/

2020 Volume 7 Number 3 (March)

http://doi.org/10.9770/jesi.2020.7.3(44)

\section{Methodology and research design}

The presented research is based on the stated theoretical review of literature that sets the background for further research and presupposes chosen online external communication tools used by companies to address their activities towards sustainability. Furtherly, content analysis of chosen online communication tools, such as companies' websites, corporate sustainability reports, GRI reports and The Communication on Progress is used to examine the extent to which each company externally communicate their sustainability activities. Moreover, the fulfillment of SDGs goals is analyzed through content analysis as well, to position each company report within stages of corporate sustainability.

\subsection{Content Analysis}

Content analysis is characterized as a type of textual analysis studying the messages or characteristics of a text to interpret meaning. Content analysis methodology has been used by several authors to study corporate sustainability and corporate social responsibility (CSR) reports (Bondy et al., 2008; Campopiano \& de Massis, 2015; Dobbs \& van Staden, 2016; Lock \& Seele, 2016; Manetti \& Toccafondi, 2014; Vurro \& Perrini, 2011; Landrum \& Ohsowski, 2018). Using UN SDGs as content categories, this study identified these 17 goals that were analyzed in terms of achievement of these goals by each company based on online external communication information drawn from companies' websites, Annual Sustainability Reports, GRI reports, and CoP participation.

Collected data were compared in order to identify whether they support each other in companies' external communication towards sustainability. Table 1 and Table 2 represent external communication tools used by companies in order to communicate sustainability: the company's website, corporate sustainability reports, GRI reports, CoP participation. They also provide information about the origin of the company. Table 3 and Table 4 represent specific SDG goals and identify which goals are achieved by the companies based on the data from their external communication tools identified in Table 1 and Table 2. Content analysis is made separately for both categories (category 1 and category 2) within the European paper industry.

The Sustainable Development Goals (SDGs) defined by the United Nations are used as a visualization tool that is sufficiently complex, analytical, flexible and general in terms of sustainability (The United Nations, 2019). Guided by the United Nations, 193 member states agreed on a global scale on the agenda of promotion of a more sustainable future, whereas SDGs address the global economic, social and environmental challenges that we are all facing, intending to leave no-one behind by 2030. Therefore, SDGs are suitable for research of sustainability in any industry as businesses play a significant role in achieving the goals (UPM, 2019).

Another criterion is companies' willingness to participate in the Communication on Progress (CoP), more specifically in the section focused on 17 Sustainable Development Goals. CoPs are publicly available on the website of the UN Global Compact and submitted directly by the participants, thus enabling companies to communicate their efforts to support and uphold the Ten Principles of the UN Global Compact. For this article, the focus is put on CoPs' section of 17 Sustainable Development Goals where companies have an opportunity to communicate their efforts in achieving these goals (The United Nations Global Compact, 2019).

\subsection{Relevant market and sample selection}

The research subject is companies that are active in the field of paper production and processing, specifically in the field of production of self-adhesive laminate that is used for self-adhesive labels manufacturing. We focus both on companies that either produce (category 1), or process (category 2) paper. Category 2 alternatively processes also another type of material for self-adhesive laminate. The market is currently clearly dominated by 


\section{ENTREPRENEURSHIP AND SUSTAINABILITY ISSUES}

ISSN 2345-0282 (online) http://jssidoi.org/jesi/

2020 Volume 7 Number 3 (March)

http://doi.org/10.9770/jesi.2020.7.3(44)

paper with over $80 \%$ of the substrate (release liner) being paper. In a typical supply chain, the producers from category 2 are customers of these belonging to category 1 .

The paper producers, being called category 1 , are generally large, specialty papermaking companies. The category 1 produces, next to numerous other paper grades, also a specific paper grade called substrate, namely release base paper (RBP), either highly super calendared kraft - being also called glassine and/or SCK, or other types of paper-based substrates like polyethylene-coated kraft and clay-coated kraft. Our research focuses on the RBP, which is used for surface treatment with silicone and lamination with other types of paper, called face stock. However, there are various types of substrates for self-adhesive labeling, whereas some of them are a plastic film-based (typically PT, PET), or are a certain type of laminate themselves (like PE coated kraft paper). According to authors' best knowledge, as well as based on self-adhesive labelling industry statistics available from industry insiders, expert companies or associations (e.g. Alexander Watson Associates, called AWA, or FINAT), there are 5 main players in Europe producing the super-calendared kraft-based substrates: United Paper Mills (UPM), Ahlstrom-Munksjö, Delfort, Sappi and Ermolli. These 5 producers (with partially multiple manufacturing locations) cover nearly $100 \%$ of the European demand for the super calendared kraft paper-based substrate for the self-adhesive labeling applications.

Category 2 comprises substrate converting companies, in fact, customers of category 1 . They are called in-house siliconizers (producing self-adhesive laminate for labeling, called label stock) and commercial siliconizers (producing siliconized release liner, used for further lamination for label stock or other self-adhesive applications). The main producers in category 2 are Avery Dennison, UPM - Raflatac, Herma, Fedrigoni Group, Ritrama, Lecta Group, Scandstick, Advanced Materials Coating / Intercoat, Mondi, Loparex, Itasa, who would cover the significant majority of the European self-adhesive laminate for labeling market.

The sample selection in both categories is therefore representative for the subject market segment, however not exhaustive particularly in category 2 , since several other, small to medium size companies do exist and operate in the subject industry. They are, however, either comparably small in size, or only to a limited extent focused on particularly self-adhesive labeling. We did not include them in the study for multiple reasons. Namely them being the individual size and the market share of the company vs. the main players mentioned above, as well as for the fact that majority of the smaller players either publish very sporadically, if at all, any information that could be used in a comparative analysis, as we did run it with the larger players.

The companies in our sample were identified drawing on authors' knowledge of the subject market, as well as using release liner and self-adhesive labeling related expert information and databases, available from industry insiders or through reports that were obtained by the researchers - particularly reports available from industry-related association and companies like Alexander Watson Associates as well as FINAT, and triaged based on the following criteria:

- $\quad$ based in Europe with headquarters (at least regional headquarters) and manufacturing facilities, typically multiple sites, thus being actively involved in production and supply to the European self-adhesive labeling market. An exception in our sample is Avery Dennison (category 2), which is headquartered in the USA, however having a strong European organizational and manufacturing base and being a very strong player on the European market.

- $\quad$ the size of the company is medium to large, typically over 100 employees

- must belong into Forest and paper products category, specifically in the field of paper production and processing in the self-adhesive labeling market

The sampling technique applied can be characterized as purposive sampling, combining critical and typical case sampling (Saunders et al., 2016), since the selected companies represent a large part of the relevant market and as such can be called trendsetters for the industry. 


\section{Research results}

http://doi.org/10.9770/jesi.2020.7.3(44)

The following chapter presents the results of research focused on online external communication towards sustainability within companies of category 1 and 2 in the field of production of self-adhesive laminate that is used for self-adhesive label production. The research questions have been organized logically, thus the answer to one question supports the answering of the following question. The results provide an overview of the industry's online external communication towards sustainability and characteristics in terms of specific areas of sustainability.

\subsection{To which extent companies externally communicate information about their activities towards sustainability?}

To answer this question, Table 1 and Table 2 were drawn to analyse which online external communication tools are used by European companies that belong into category 1 and 2 and are active in the field of paper production and processing within paper industry for self-adhesive labelling.

Table 1. Online external communication tools used by category 1

\begin{tabular}{|c|l|l|c|c|c|c|c|}
\hline \multicolumn{9}{|c|}{ Category 1: Paper producers } \\
\hline $\begin{array}{c}\text { Reference } \\
\text { number }\end{array}$ & Company name & Country & GRI index & Website & $\begin{array}{c}\text { Reports } \\
\text { available on } \\
\text { websites }\end{array}$ & $\begin{array}{c}\text { CoP } \\
\text { participation }\end{array}$ & Total \\
\hline 1 & Delfort & Austria & $\mathrm{x}$ & $\mathrm{X}$ & $\mathrm{x}$ & & 3 \\
\hline 2 & UPM Kymmene & Finland & $\mathrm{x}$ & $\mathrm{X}$ & $\mathrm{x}$ & $\mathrm{x}$ & 4 \\
\hline 3 & Ahlstrom-Munksjo & Finland & $\mathrm{x}$ & $\mathrm{X}$ & $\mathrm{x}$ & $\mathrm{x}$ & 4 \\
\hline 4 & Sappi & Belgium & $\mathrm{x}$ & $\mathrm{X}$ & $\mathrm{x}$ & $\mathrm{x}$ & 4 \\
\hline 5 & Ermolli & Italy & & $\mathrm{X}$ & & & 1 \\
\hline Total & & & & 5 & 4 & & 3 \\
\hline
\end{tabular}

Source: Authors' own research

According to the results, paper producers (category 1) use their companies' websites, Annual Sustainability Reports, GRI and also participate in CoP to externally communicate their activities towards sustainability. The only exception is Italian paper producer Ermolli who relies solely on its website and communicated information regarding sustainability is sporadic (Ermolli, 2019). On the other hand, Delfort, UPM Kymmene, Ahlstrom-Munksjo and Sappi communicate their sustainability efforts to large extent with documents, reports, and websites being very complex, well-arranged, informative and thoughtful (GRI, 2019; The United Nations Global Compact, 2018; Delfort, 2019; Sappi, 2018; UPM, 2019; Ahlstrom-Munksjo, 2018). Therefore, these companies can provide their on-line visitors and stakeholders with valuable information about their sustainability efforts and performance. Delfort does not participate in the Communication on Progress (CoP), however, based on their other external communication tools, the company delivers more than a sufficient amount of information about their sustainability activities (Delfort, 2019). Overall, category 1 companies possess a strong base of digitally enabled well-structured external communication tools that are displayed online and are available for anyone interested in their sustainability efforts and plans. Therefore, we conclude that companies belonging to category 1 are using external communication tools to provide information about sustainability to a great extent. 
ENTREPRENEURSHIP AND SUSTAINABILITY ISSUES

ISSN 2345-0282 (online) http://jssidoi.org/jesi/

2020 Volume 7 Number 3 (March)

http://doi.org/10.9770/jesi.2020.7.3(44)

Table 2. Online external communication tools used by category 2

\begin{tabular}{|c|c|c|c|c|c|c|c|}
\hline \multicolumn{8}{|c|}{ Category 2: Downstream users, customers of the substrate producers } \\
\hline $\begin{array}{l}\text { Reference } \\
\text { number }\end{array}$ & Company name & Country & GRI index & Website & $\begin{array}{c}\text { Reports } \\
\text { available } \\
\text { on } \\
\text { websites } \\
\end{array}$ & $\begin{array}{c}\mathrm{CoP} \\
\text { participation }\end{array}$ & Total \\
\hline 6 & UPM Raflatac & Finland & & $\mathrm{x}$ & $\mathrm{x}$ & & 2 \\
\hline 7 & Herma & Germany & & $\mathrm{x}$ & & & 1 \\
\hline 8 & Fedrigoni Group & Italy & & $\mathrm{x}$ & $\mathrm{x}$ & & 2 \\
\hline 9 & Ritrama & Italy & & $\mathrm{x}$ & & & 1 \\
\hline 10 & Scandstick & Sweden & & $\mathrm{x}$ & & & 1 \\
\hline 11 & Lecta Group & Spain & & $\mathrm{x}$ & $\mathrm{x}$ & $\mathrm{x}$ & 3 \\
\hline 12 & Avery Dennison & USA / The Netherlands & $\mathrm{x}$ & $\mathrm{x}$ & $\mathrm{x}$ & & 3 \\
\hline 13 & AMC / Intercoat & Germany & & $\mathrm{x}$ & & & 1 \\
\hline 14 & Mondi & Austria & $\mathrm{x}$ & $\mathrm{x}$ & $\mathrm{x}$ & $\mathrm{x}$ & 4 \\
\hline 15 & Loparex & USA / The Netherlands & & $\mathrm{x}$ & $\mathrm{x}$ & & 2 \\
\hline 16 & Itasa & Spain & & $\mathrm{x}$ & $\mathrm{x}$ & & 2 \\
\hline Total & & & 2 & 11 & 7 & 2 & \\
\hline
\end{tabular}

Source: Authors' own research

On the other hand, based on the results, a number of category 2 companies generally lack behind to provide sufficient information and externally communicate their sustainability activities. Only one out of thirteen companies covering the European market of category 2 externally communicate their sustainability activities through all chosen communication tools. Mondi uses all four channels (Mondi, 2019). Right behind Mondi is Lecta Group, using sufficiently all chosen communication tools besides GRI (Lecta, 2019). Avery Dennison uses three tools as well, to communicate their sustainability efforts: website, company's reports (even though the structure is a bit different, they are very comprehensive and well-structured) and GRI. They also won Innovations in Sustainability Award for their work with EcoVadis (EcoVadis, 2019). UPM Raflatac, Loparex, and Fedrigoni rely solely on their websites and Annual Sustainability Reports (UPM Raflatac, 2019; Loparex, 2019; Fedrigoni, 2019). Itasa uses these two tools as well, however, information is outdated (last report from 2016) and report is not available in English language (Itasa, 2016), although they do have basic information about sustainability activities on their website in English available (Itasa, 2019). Other analyzed companies only use websites for their external communication about sustainability. However, the information provided is not sufficient enough. Scandstick and AMC mention sustainability very marginally, general information regarding sustainability comprises of a very few sentences. Thus, companies of category 2 externally communicate information about their sustainability activities with the help of digitally enabled tools only to a small extent.

\subsection{Which SDGs are the most common within communication strategy of the sample of companies?}

Similarly, to answer which SDGs are the most common ones, Table 3 and Table 4 were conducted to analyze which of the 17 SDGs are met by companies in categories 1 and 2. Consequently, Table 3 and Table 4 examine which of these goals are externally communicated through their online external communication tools, more specifically their websites, Annual Sustainability Reports, GRI index and participation in CoP. 
ENTREPRENEURSHIP AND SUSTAINABILITY ISSUES

ISSN 2345-0282 (online) http://jssidoi.org/jesi/

2020 Volume 7 Number 3 (March)

http://doi.org/10.9770/jesi.2020.7.3(44)

Table 3. Paper producers' compliance with Sustainable Development Goals

\begin{tabular}{|c|c|c|c|c|c|c|c|c|c|c|c|c|c|c|c|c|c|c|c|}
\hline \multicolumn{20}{|c|}{ Category 1: Paper producers } \\
\hline \multirow{2}{*}{$\begin{array}{c}\text { Reference } \\
\text { number }\end{array}$} & \multirow{2}{*}{$\begin{array}{c}\text { Company } \\
\text { name }\end{array}$} & \multicolumn{17}{|c|}{ SDGs } & \multirow[b]{2}{*}{ Tota } \\
\hline & & 1 & 2 & 3 & 4 & 5 & 6 & 7 & 8 & 9 & 10 & 11 & 12 & 13 & 14 & 15 & 16 & 17 & \\
\hline 1 & Delfort & & & $\mathrm{x}$ & & $\mathrm{x}$ & $\mathrm{X}$ & $\mathrm{x}$ & $\mathrm{x}$ & $\mathrm{x}$ & $\mathrm{x}$ & & $\mathrm{x}$ & $\mathrm{x}$ & & $\mathrm{x}$ & & & 10 \\
\hline 2 & $\begin{array}{l}\text { UPM } \\
\text { Kymmene }\end{array}$ & & & $\mathrm{X}$ & $\mathrm{X}$ & $\mathrm{x}$ & $\mathrm{X}$ & & $\mathrm{x}$ & $\mathrm{x}$ & & & $\mathrm{x}$ & $\mathrm{X}$ & & $\mathrm{x}$ & $\mathrm{x}$ & $\mathrm{X}$ & 11 \\
\hline 3 & $\begin{array}{l}\text { Ahlstrom- } \\
\text { Munksjo }\end{array}$ & & & $\mathrm{X}$ & & $\mathrm{x}$ & $\mathrm{X}$ & $\mathrm{x}$ & $\mathrm{x}$ & $\mathrm{x}$ & & & $\mathrm{x}$ & & $\mathrm{x}$ & $\mathrm{x}$ & $\mathrm{x}$ & $\mathrm{x}$ & 11 \\
\hline 4 & Sappi & $\mathrm{x}$ & & $\mathrm{x}$ & $\mathrm{x}$ & & $\mathrm{x}$ & $\mathrm{x}$ & $\mathrm{x}$ & $\mathrm{x}$ & & & $\mathrm{x}$ & $\mathrm{x}$ & & $\mathrm{x}$ & $\mathrm{x}$ & $\mathrm{x}$ & 12 \\
\hline 5 & Ermolli & & & & & & $\mathrm{x}$ & $\mathrm{x}$ & & & & & $\mathrm{x}$ & & & & & & 3 \\
\hline & Total & 1 & 0 & 4 & 2 & 3 & 5 & 4 & 4 & 4 & 1 & 0 & 5 & 3 & 1 & 4 & 3 & 3 & \\
\hline
\end{tabular}

Source: Authors' own research

Delfort has a very strong and wide base with a focus on several sustainability aspects and goals. They do not refer directly to SDGs, however, external communication of their activities regarding different sustainability goals shows that they comply with 10 out of 17 SDGs in total. Some goals are communicated more in-depth, such as effective water consumption and life on land, some of them with less intensity, such as gender equality and reduction of inequalities (Delfort, 2019).

UPM talks on their website about responsibility, rather than sustainability, and their goals are directly linked to SDGs, with focus on 11 SDGs, as communicated through their digitally-enabled communication tools (Lundgren, 2019). Ahlstrom-Munksjo also seeks to advance the UN SDGs across their value chain by aligning nine material topics with the UN SDG framework to contribute or reduce a negative impact on a minimum of 11 SDGs across their value chain (Ahlstrom-Munksjo, 2018). Sappi also works in alignment with SDGs and they work to integrate the principles and aspirations of the UN SDGs into their everyday business activities, covering 12 SDGs (Sappi, 2018). Ermolli only covers 3 SDGs without any reference to the SDGs framework itself (Ermolli, 2019).

The most common SDGs that all companies of category 1 target and communicate are Clean Water and Sanitation (6) and Responsible Consumption and Production (12). Other goals of high priority are communicated by four companies that report to a great extent their sustainability activities.

These goals are Good Health and Well-Being (3), Decent Work and Economic Growth (8), Industry, Innovation and Infrastructure (9) and Life on Land (15). Affordable and Clean Energy (7) is also in the viewfinder of four companies. Other common goals communicated by three companies are Gender Equality (5), Climate Action (13) and Partnerships for the Goals (17). Less overall attention is drawn to No Poverty (1), Quality Education (4), Reduced Inequalities (10) and Life Below Water (14). SDGs of Zero Hunger (2) and Sustainable Cities and Communities (11) are not communicated by any company of category 1 . 
Table 4. Downstream users' compliance with Sustainable Development Goals

\begin{tabular}{|c|c|c|c|c|c|c|c|c|c|c|c|c|c|c|c|c|c|c|c|}
\hline \multicolumn{20}{|c|}{ Category 2: Downstream users, customers of the substrate producers } \\
\hline \multirow{2}{*}{$\begin{array}{l}\text { Reference } \\
\text { number }\end{array}$} & \multirow{2}{*}{$\begin{array}{l}\text { Company } \\
\text { name }\end{array}$} & \multicolumn{17}{|c|}{ SDGs } & \multirow[b]{2}{*}{ Total } \\
\hline & & 1 & 2 & 3 & 4 & 5 & 6 & 7 & 8 & 9 & 10 & 11 & 12 & 13 & 14 & 15 & 16 & 17 & \\
\hline 6 & \begin{tabular}{|l|} 
UPM \\
Raflatac \\
\end{tabular} & & & & & & $\mathrm{x}$ & $\mathrm{x}$ & $\mathrm{x}$ & & & & $\mathrm{x}$ & $\mathrm{x}$ & & $\mathrm{x}$ & & & 6 \\
\hline 7 & Herma & & & & & & & & $\mathrm{x}$ & $\mathrm{x}$ & & & $\mathrm{x}$ & & & $\mathrm{x}$ & & & 4 \\
\hline 8 & $\begin{array}{l}\text { Fedrigoni } \\
\text { Group }\end{array}$ & & & $\mathrm{x}$ & $\mathrm{x}$ & & $\mathrm{x}$ & & & & & $\mathrm{x}$ & $\mathrm{x}$ & $\mathrm{x}$ & & & & & 6 \\
\hline 9 & Ritrama & & & $\mathrm{x}$ & & $\mathrm{x}$ & & $\mathrm{x}$ & & & $\mathrm{x}$ & & $\mathrm{x}$ & & & $\mathrm{x}$ & & & 6 \\
\hline 10 & - & & & & & & & & & & & & & & & & & & 0 \\
\hline 11 & Lecta Group & & & & & & & & & & & & $\mathrm{x}$ & $\mathrm{x}$ & $\mathrm{x}$ & $\mathrm{x}$ & & $\mathrm{x}$ & 5 \\
\hline 12 & \begin{tabular}{|l|} 
Avery \\
Dennison \\
\end{tabular} & & $\mathrm{x}$ & $\mathrm{x}$ & $\mathrm{x}$ & $\mathrm{x}$ & $\mathrm{x}$ & $\mathrm{x}$ & $\mathrm{x}$ & & $\mathrm{x}$ & $\mathrm{x}$ & $\mathrm{x}$ & & & & & $\mathrm{x}$ & 11 \\
\hline 13 & \begin{tabular}{|l|} 
AMC \\
Intercoat \\
\end{tabular} & & & & & & & & & & & & $\mathrm{x}$ & & & & & $\mathrm{x}$ & 2 \\
\hline 14 & Mondi & $\mathrm{x}$ & $\mathrm{x}$ & $\mathrm{x}$ & $\mathrm{x}$ & $\mathrm{x}$ & $\mathrm{x}$ & $\mathrm{x}$ & $\mathrm{x}$ & $\mathrm{x}$ & & $\mathrm{x}$ & $\mathrm{x}$ & $\mathrm{x}$ & $\mathrm{x}$ & $\mathrm{x}$ & & $\mathrm{x}$ & 15 \\
\hline 15 & Loparex & & & $\mathrm{x}$ & & $\mathrm{x}$ & & & & & $\mathrm{x}$ & & $\mathrm{x}$ & & & & & & 4 \\
\hline 16 & Itasa & & & & & & & & $\mathrm{x}$ & & & & & & & $\mathrm{x}$ & & $\mathrm{x}$ & 3 \\
\hline & Total & 1 & 2 & 5 & 3 & 4 & 4 & 4 & 5 & 2 & 3 & 3 & 9 & 4 & 2 & 6 & 0 & 5 & \\
\hline
\end{tabular}

Source: Authors' own research

Based on the results, category 2 varies in terms of communication regarding the fulfillment of UN SDGs. Company Scandstick was excluded from further research on SDGs as it did not provide sufficient information regarding sustainability through its external communication tools. On the other hand, UPM Raflatac is highly committed to UN SDGs aiming towards a stronger sustainability culture, improved employee engagement and increased transparency (UPM RAFLATAC, 2019). Other companies do not directly refer to UN SDGs in their online external communication, except for Lecta Group who participated in Communication on Progress (The United Nations Global Compact, 2019). Even though Avery Dennison does not directly refer to SDGs, they provide a comprehensive, well-structured and complex set of goals and activities within their sustainability efforts, indirectly covering 11 SDGs. (Avery Dennison, 2019). Furtherly, based on information provided, also other examined companies still cover SDGs through their communicated activities.

SDGs of category 2 are very fragmented. The most common SDG communicated by eight companies is Responsible Consumption and Production (12), followed by Life on Land (15) communicated by six companies. Other common SDGs are Good Health and Well-Being (3), Decent Work and Economic Growth (8), Climate Action (13) and Partnerships for the Goals (17). Other SDGs were communicated by four companies and less, and thus, they are not considered the most common considering the sample of category 2.

\section{Conclusions}

Companies' communication with the external world, when it comes to sustainable development, is considered very important (Bilinska-Reformat et al., 2018). Our research has shown that communication, particularly via digital media, about sustainability performance becomes an inherent part of the overall communication throughout companies (Reilly \& Hynan, 2014), including major paper producing and paper converting companies active in the field of self-adhesive labeling in Europe. 


\section{ENTREPRENEURSHIP AND SUSTAINABILITY ISSUES}

ISSN 2345-0282 (online) http://jssidoi.org/jesi/

2020 Volume 7 Number 3 (March)

http://doi.org/10.9770/jesi.2020.7.3(44)

Papermaking companies, belonging to category 1, use digital technologies for on-line communication widely. On the contrary, paper processing companies, belonging to category 2, although generally being active in using on-line tools, communicate about sustainability to a much less extent. One of the possible reasons can be that the paper producing industry, using natural resources in form of wooden fibres, feels a stronger need to reach out for their stakeholders with comprehensive information about its sustainability-related performance.

Further on, we have found a positive correlation between the use of the on-line communication about sustainability generally, and focus on SDGs, in terms of quantity and intensity - a number of tools used, as well as a number of goals communicated - and quality - the content of the communication. Companies seem to follow the SDGs framework as a guidance and a benchmark for what to focus on in the sustainability direction.

Although it is not explicitly measured, it is obvious that the intensity of the communication is positively correlated with the size of the company, in both categories. Some of the companies in the sample (three out of five category 1 companies, as well as Avery Dennison, UPM-Raflatac and Mondi in category 2) reach multi-billion EUR turnover, are globally acting companies with large production sites and customers in multiple countries and continents. Their level of communication on sustainability is more intense than that of the others. This being said does not necessarily mean that the others would be less concerned about sustainability, however, their level of communication is less intense. This may be attributable both to resource availability, as well as to the fact of an objective or subjective need of the large, stock-listed companies, to address their stakeholders, namely (but not only) shareholders with specific information related to adherence to SDGs.

\section{Research limitations, avenues for further research}

The selected companies represent the vast majority of the European self-adhesive labeling paper production and processing industry, thus the examined sample is highly representative for the given field of industry. Within the entire European paper industry, significantly contributing to over 80 million tons of paper per year consumed in Europe, there is a large number of other companies and industry segments not included in the present research. What sustainable development goals they focus on and how they communicate them could help to expand the understanding of the communication strategy in the entire industry, particularly with a focus on digital tools.

Second, comparison with other, non-paper industries, esp. from the field of manufacturing on basis of non-renewable resources, could contribute to the identification of the differences in the communication about the sustainable development goals' adherence and progress.

Third, understanding of why companies select particular goals and communicate about these while neglecting the others could be improved. Particularly, whether the other goals are considered irrelevant, or are out of the scope, out of the focus or out of the interest.

Fourth, the interlinkage of the goals with the extant business model and its components is to be examined. Is it mainly the value proposition, value creation, value delivery or value capture (D'Amato, 2020), being the key four identified components of a business model, that are most impacted by the communication of the companies about their performance in the field of sustainable development?

Fifth, since we relied only on the officially and publicly available sources of information, we did not examine the possible gap between what is being communicated towards the external world and what is being done, whether and to what extent the companies live what they communicate. 


\section{ENTREPRENEURSHIP AND SUSTAINABILITY ISSUES}

ISSN 2345-0282 (online) http://jssidoi.org/jesi/

2020 Volume 7 Number 3 (March)

http://doi.org/10.9770/jesi.2020.7.3(44)

\section{References}

Ahlstrom-Munksjo, 2018. Annual \& Sustainability Report 2018. [online] Available at: https://www.ahlstrom-munksjo.com/ [Accessed 10 October 2019].

Ahlstrom-Munksjo, 2019. Sustainable everyday life. [online] Available at: https://www.ahlstrom-munksjo.com/ [Accessed 10 October 2019].

Avery Dennison, 2017. Avery Dennison 2014-2016 Sustainability Report. Available at: https://sustainability.averydennison.com/ [Accessed 10 October 2019].

Avery Dennison, 2019. Sustainability. [online] Available at: https://sustainability.averydennison.com/ [Accessed 10 October 2019].

AWA, 2016. AWA Europea Release Liner Market Study 2016.

Bilinska-Reformat, K.; Kucharska, B.; Twardzik, M.; Dolega, L. 2019. Sustainable development concept and creation of innovative business models by retail chains, International Journal of Retail \& Distribution Management 47 (1): $2-18$. http://dx.doi.org/10.1108/IJRDM-04-2017-0071

Bondy, K.; Matten, D.; Moon, J. 2008. Multinational corporation codes of conduct: governance tools for corporate social responsibility? Corporate Governance 16(4): 294-311. http://dx.doi.org/10.1111/j.1467-8683.2008.00694.x

Boons, F.; Laasch, O. 2019. Business Models for Sustainable Development: A Process Perspective, Journal of Business Models 7 (1): 9-12. Retrieved from http://journalofbusinessmodels.com/vol-7-no-1-2019/vol-7-no-1-2019-pp-9-12/

Calace, D. 2016. Battle of Giants: GRI vs SASB vs IR. [online] Available at: http://www.greenbiz.com/ [Accessed 10 October 2019].

Campopiano, G.; de Massis, A. 2015. Corporate social responsibility reporting: a content analysis in family and non-family firms. Journal of Business Ethics 129: 511-534. http://dx.doi.org/10.1007/s10551-014-2174-Z

Castelo-Branco, I.; Cruz-Jesus, F.; Oliveira, T. 2019. Assessing Industry 4.0 readiness in manufacturing: Evidence for the European Union, Computers in Industry 107: 22-23. http://dx.doi.org/10.1016/j.compind.2019.01.007

Chierici, E.; Copani, G. 2016. Remanufacturing with Upgrade PSS for New Sustainable Business Models, Procedia CIRP 47: 531-536, http://dx.doi.org/10.1016/j.procir.2016.03.055

D'Amato, D.; Veijonaho, S.; Toppinen, A. 2020. Towards Sustainability? Forest-based circular bioeconomy business models in Finnish SMEs, Forest Policy and Economics 110 (101848): 1-11. http://dx.doi.org/10.1016/j.forpol.2018.12.004

Delfort, 2019. HIGHLIGHTS sustainability report 2019: Resources x Responsibility. [online] Available at: https://www.delfortgroup.com/ [Accessed 10 October 2019].

Delfort, 2019. We live sustainability. [online] Available at: https://www.delfortgroup.com/ [Accessed 10 October 2019].

Dobbs, S.; van Staden, C. 2016. Motivations for corporate social and environmental reporting: New Zealand evidence. Sustainability Accounting, Management and Policy Journal 7(3): 449-472. http://dx.doi.org/10.1108/SAMPJ-08-2015-0070

EcoVadis, 2019. Avery Dennison Wins 2019 Innovations in Sustainability Award for Its Work with EcoVadis. [online] Available at: https://resources.ecovadis.com/ [Accessed 10 October 2019].

Elkington, J. 1998. Accounting for the tripple bottom line, Measuring Business Excellence 2(3): 18-22. http://dx.doi.org/10.1108/eb025539

Ermolli, 2019. Ambiente. [online] Available at: http://www.ermolli.it/ [Accessed 10 October 2019].

Ernst \& Young, 2014. Sustainability Reporting: the Time is Now. [online] Available at: http://www.ey.com/ [Accessed 10 October 2019]. 


\section{ENTREPRENEURSHIP AND SUSTAINABILITY ISSUES}

ISSN 2345-0282 (online) http://jssidoi.org/jesi/

2020 Volume 7 Number 3 (March)

http://doi.org/10.9770/jesi.2020.7.3(44)

Ernst \& Young, 2016. Value of Sustainability Reporting: a study by EY and Boston College Center for Corporate Citizenship. [online] Available at: http://www.ey.com/ [Accessed 10 October 2019].

European Paper Recycling Council. 2017. Monitoring Report 2017, European Declaration on Paper Recycling 2016-2020, European Paper Recycling Council, read on-line 17.11.2019, Retrieved from http://www.paperforrecycling.eu/download/900/

Evans, S.; Vladimirova, D.; Holgado, M.; van Fossen, K.; Yang, M.; Silva, E. A.; Barlow, C.Y. 2017. Business Model Innovation for Sustainability: Towards a Unified Perspective for Creation of Sustainable Business Models, Business Strategy and the Environment 25: 597-608. http://dx.doi.org/10.1002/bse.1939

Fedrigoni, 2019. Sustainability. [online] Available at: https://www.fedrigoni.com/en/ [Accessed 10 October 2019].

GRI, 2015. Sappi Europe. [online] Available at: https://database.globalreporting.org/ [Accessed 10 October 2019].

GRI, 2017. Ahlstrom-Munksjo. [online] Available at: https://database.globalreporting.org/ [Accessed 10 October 2019].

GRI, 2017. Avery Dennison. [online] Available at: https://database.globalreporting.org/ [Accessed 10 October 2019].

GRI, 2018. Delfort. [online] Available at: https://database.globalreporting.org/ [Accessed 10 October 2019].

GRI, 2018. Mondi Business Paper (former Neusiedler). [online] Available at: https://database.globalreporting.org/ [Accessed 10 October 2019].

GRI, 2019. GRI AND SUSTAINABILITY REPORTING. [online] Available at: http://www.globalreporting.org/ [Accessed 10 October 2019].

GRI, 2019. Sustainable Development Goals. [online] Available at: http://www.globalreporting.org/ [Accessed 10 October 2019].

GRI, 2019. UPM-Kymmene. [online] Available at: https://database.globalreporting.org/ [Accessed 10 October 2019].

HERMA Company, 2019. Our Environment. [online] Available at: https://www.herma.com/ [Accessed 10 October 2019].

King, A.; Bartels, W.; McKenzie, M.; Austin, E. 2015. Currents of Change: the KPMG Survey of Corporate Responsibility Reporting 2015. [online] Available at: http://www.kpmg.com/ [Accessed 10 October 2019].

Itasa, 2016. Declaración Ambiental. [online] Available at: https://www.itasa.es/en/ [Accessed 10 October 2019].

Itasa, 2019. Committed to our surroundings. Itasa. [online] Available at: https://www.itasa.es/en/ [Accessed 10 October 2019].

Ki, E-J.; Shin, S. 2015. Organization sustainability communication (OSC): Similarities and differences of OSC messages in the United States and South Korea, Computers in Human Behaviour 48: 36-43. http://dx.doi.org/10.1016/chb.2015.01.029

Kirchherr, J.; Reike, D.; Hekkert, M. 2017. Conceptualizing the circular economy: An analysis of 114 definitions, Resources, Conservation \& Recycling 127: 221-232. http://dx.doi.org/10.1016/j.resconrec.2017.09.005

Landrum, N. E.; Ohsowski, B. 2018. Identifying Worldviews on Corporate Sustainability: A Content Analysis of Corporate Sustainability Reports, Business Strategy and the Environment 27(1): 128-151. http://dx.doi.org/10.1002/bse.1989

Lecta, 2019. A responsible company. [online] Available at: https://www.lecta.com/en/ [Accessed 10 October 2019].

Lecta, 2019. Environmental Report 2019: Challenges 2019-2020. [online] Available at: https://www.lecta.com/en/ [Accessed 10 October 2019].

Lock, I.; Seele, P. 2016. The credibility of CSR (corporate social responsibility) reports in Europe: evidence from a quantitative content analysis in 11 countries. Journal of Cleaner Production 122: 186-200. http://dx.doi.org/10.1016/j.jclepro.2016.02.060

Loparex, 2019. Code of Conduct. [online] Available at: https://loparex.com/ [Accessed 10 October 2019].

Loparex, 2019. The Loparex Value. [online] Available at: https://loparex.com/[Accessed 10 October 2019].

Lundgren, S. 2019. Shared goals with UN. [online] Available at: https://www.upm.com/ [Accessed 10 October 2019]. 


\section{ENTREPRENEURSHIP AND SUSTAINABILITY ISSUES}

ISSN 2345-0282 (online) http://jssidoi.org/jesi/

2020 Volume 7 Number 3 (March)

http://doi.org/10.9770/jesi.2020.7.3(44)

Manetti, G.; Toccafondi, S. 2014. Defining the content of sustainability reports in nonprofit organizations: do stakeholders really matter? Journal of Nonprofit and Public Sector Marketing 26(1): 35-61. http://dx.doi.org/10.1080/10495142.2013.857498

Mondi, 2019. Sustainability. [online] Available at: https://www.mondigroup.com/en/[Accessed 10 October 2019].

Mondi, 2019. Sustainable Development Report 2018: Sustainable packaging and paper by design. [online] Available at: https://www.mondigroup.com/en/ [Accessed 10 October 2019].

OECD, 2017. Digital Economy Outlook 2017. [online] Available at: http://oecd.org/ [Accessed 10 October 2019].

Pasztor, S. 2016. Exploring the framing of diversity rhetoric in 'top-rated in diversity' organizations, International Journal of Business Communication, 1-21. http://dx.doi.org/10.1177/2329488416664175

Petrenko, Y.; Vechkinzova, E.; Antonov, V. 2019. Transition from the industrial clusters to the smart specialization of the regions in Kazakhstan, Insights into Regional Development 1(2): 118-128. https://doi.org/10.9770/ird.2019.1.2(3)

Point, S.; Singh, V. 2003. Defining and dimensionalising diversity: evidence from corporate websites across Europe, European Journal of Management 21(6): 750-761. http://dx.doi.org/10.1016/j.emj.2003.09.015

Prodani, R.; Bushati, J.; Andersons, A. 2019. An assessment of impact of information and communication technology in enterprizes of Korça region. Insights into Regional Development, 1(4), 333-342. https://doi.org/10.9770/ird.2019.1.4(4)

Maier, C. D.; Ravazzani, S. 2018. Bridging diversity management and CSR in online external communication, Corporate Communications: An International Journal 24(2): 269-286. http://dx.doi.org/10.1108/CCIJ-01-2018-0015

Potting, J.; Hekkert, M.; Worrell, E.; \& Hanemaaijer, A. 2016. Circular Economy: Measuring Innovation in the Product Chain. Retrieved from https://dspace.library.uu.nl/handle/1874/358310

Raith, M. G.; Seibold, N. 2018. Building Business Models around Sustainable Development Goals, Journal of Business Models 6(2): 7177. Retrieved from http://journalofbusinessmodels.com/vol-6-no-2-2018/vol-6-no-2-pp-71-77/

Ravazzani, S. 2016. Understanding approaches for managing diversity in the workplace: an empirical investigation in Italy, Equality, Diversity and Inclusion: An International Journal 35(2): 154-168. http://dx.doi.org/10.1108/EDI-08-2014-0062

Reilly, A. H.; Hynan, K. A. 2014. Corporate communication, sustainability, and social media: It's not easy (really) being green, Business Horizons 57: 747-758. http://dx.doi.org/10.1016/j.bushor.2014.07.008

Reilly, A. H.; Naznin, L. 2018. External Communication about Sustainability: Corporate Social Responsibility Reports and Social Media Activity, Environmental Communication 12(5): 621-637. http://dx.doi.org/10.1080/17524032.2018.1424009

Ritrama, 2019. Sustainability: A careful and responsible approach. [online] Available at: https://www.ritrama.com/en/_[Accessed 10 October 2019].

Sappi, 2018. 2018 Group Sustainability Report. [online] Available at: https://www.sappi.com/ [Accessed 10 October 2019].

Sappi, 2019. Sustainability in Sappi group. [online] Available at: https://www.sappi.com/ [Accessed 10 October 2019].

Saunders, M.; Lewis, P.; Thornhill, A. 2016, Research Methods for Business Students, seventh edition. Harlow: Published by Pearson Education Limited

Scandstick, 2019. About Us. [online] Available at: https://www.scandstick.se/ [Accessed 10 October 2019].

Schaltegger, S.; Hansen, E.G.; Lüdeke-Freund, F. 2016. Business models for Sustainability: Origins, Present Research, and Future Avenues, Organization \& Environment 29(1): 3-10. http://dx.doi.org/10.1177/1086026615599806

Stubbs, W.; Higgins, C.; Milne, M. 2013. Why do companies not produce sustainability reports? Business Strategy and the Environment 22(7): 456-470. http://dx.doi.org/10.1002/bse.1756

The United Nations, 2019. About Sustainable Development Goals. [online] Available at: http://www.un.org/en/ [Accessed 10 October 2019]. 


\section{ENTREPRENEURSHIP AND SUSTAINABILITY ISSUES}

ISSN 2345-0282 (online) http://jssidoi.org/jesi/

2020 Volume 7 Number 3 (March)

http://doi.org/10.9770/jesi.2020.7.3(44)

The United Nations, 2019. 17 Goals to Transform Our World. [online] Available at: http://www.un.org/en/[Accessed 10 October 2019].

The United Nations, 2019. Sustainable Development Goals. [online] Available at: http://www.un.org/en/ [Accessed 10 October 2019].

The United Nations Global Compact, 2019. The Communication on Progress (CoP) in Brief. [online] Available at: https://www.unglobalcompact.org [Accessed 10 October 2019].

The United Nations Global Compact, 2018. Communication on Progress: Ahlstrom-Munksjo. [online] Available at: https://www.unglobalcompact.org/[Accessed 10 October 2019].

The United Nations Global Compact, 2018. Communication on Progress: Mondi. [online] Available at: https://www.unglobalcompact.org/ [Accessed 10 October 2019].

The United Nations Global Compact, 2018. Communication on Progress: Sappi. [online] Available at: https://www.unglobalcompact.org/ [Accessed 10 October 2019].

The United Nations Global Compact, 2018. Communication on Progress: UPM-Kymmene Corporation. [online] Available at: https://www.unglobalcompact.org/ [Accessed 10 October 2019].

The United Nations Global Compact, 2019. Communication on Progress: Lecta Group. [online] Available at: https://www.unglobalcompact.org/ [Accessed 10 October 2019].

The United Nations Global Compact, 2019. Why report? [online] Available at: https://www.unglobalcompact.org [Accessed 10 October 2019].

Tvaronavičienè, M. 2012. Should Consistent Patterns be Traced: Impact of Globalization on Certain Sustainable Development Facets, Socialiniu Mokslu Studijos 4(2): 443-468. Retrieved from http://search.proquest.com/docview/1426203342/

Tvaronavičienè, M. 2018. Preconditions of Sustainable Entrepreneurship: Estimating of Brexit Scenarios Impact on Macroeconomic Environment. Polish Journal of Management Studies 17(2): 222-234. http://dx.doi.org/10.17512/pjms.2018.17.2.19

UPM, 2019. Supporting the UN Sustainable Development Goals. [online] Available at: https://www.upm.com/ [Accessed 10 October 2019].

UPM, 2019. Responsibility. [online] Available at: https://www.upm.com/ [Accessed 10 October 2019].

UPM RAFLATAC, 2019. Sustainable Development Goals. [online] Available at: https://www.upmraflatac.com/ [Accessed 10 October 2019].

UPM RAFLATAC, 2019. Leading in Sustainable Labelling. [online] Available at: https://www.upmraflatac.com/ [Accessed 10 October 2019].

Vurro, C.; Perrini, F. 2011. Making the most of corporate social responsibility reporting: disclosure structure and its impact on performance. Corporate Governance 11(4): 459-474. http://dx.doi.org/10.1108/14720701111159280 


\section{Aknowledgements}

This paper was supported by the research project: The challenges of digital transformation in the context of globalization, which is founded by Specific Research of FBM BUT, grant number FP-J-19-5909.
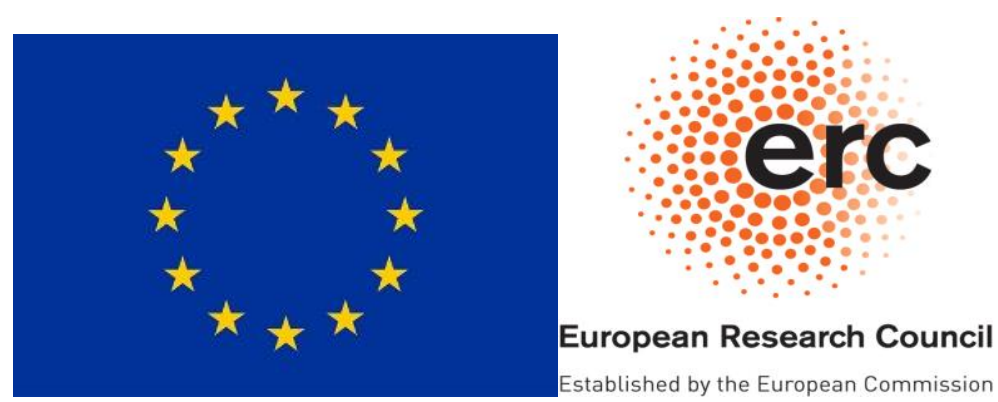

Mariana TESǍ̆OVÁ is a PhD student at the Faculty of Business and Management of Brno University of Technology in the Czech Republic. Dissertation focuses on the topic of sustainable innovations of business models. Research interests: business models, sustainability, digitalization, sustainable innovations.

ORCID ID: orcid.org/0000-0002-1515-0357

Aleš KRMELA is a PhD student at the Faculty of Business and Management of Brno University of Technology in the Czech Republic. Research interests: business models, sustainability.

ORCID ID: orcid.org/0000-0001-6774-8951

Iveta ŠIMBEROVÁ is associate professor and also the vice-dean for international relations of the Faculty of Business and Management at Brno University of Technology in the Czech Republic. Her main research areas are: sustainability, business models: innovations and dynamism. Her publication list involved more than 20 original articles in scientific reviewed journals, 6 specialized books (co-author of specified chapters, 67 articles in reviewed conference proceedings).

ORCID ID: orcid.org/0000-0002-9236-4439 